\title{
Dust exposure, dust recovered from the lung, and associated pathology in a group of British coalminers
}

\author{
A N DOUGLAS, A ROBERTSON, J S CHAPMAN, V A RUCKLEY \\ From the Institute of Occupational Medicine, Edinburgh EH8 9SU, UK
}

\begin{abstract}
The relation between dust exposure, retained lung dust, and pneumoconiosis have been examined in 430 dead coalminers who had participated in a large scale epidemiological survey of respiratory health. The men were divided into three groups depending on the presence of particular lesions in their lungs. Lungs containing no fibrotic lesions in excess of $1 \mathrm{~mm}$ were included in the " $M$ " group, those with fibrotic lesions of between $1 \mathrm{~mm}$ and $9 \mathrm{~mm}$ in diameter were included in the "F" group, and those with any lesion $10 \mathrm{~mm}$ or more were categorised as having progressive massive fibrosis (PMF). The men were further divided into four groups according to the rank of coal mined at the colliery of employment. The mean weight of lung dust increased over the pathological range $(\mathrm{M} \rightarrow \mathrm{F} \rightarrow \mathrm{PMF})$ regardless of the rank of coal mined. The men with PMF had not received unusually high exposures to dust in life but were found to have accumulated more dust in their lungs per unit of dust exposure than men without PMF, providing further evidence for differences in the patterns of deposition or clearance, or both, of dust in these men compared with those who do not develop PMF. For men who had mined the higher rank coals there was no difference in the composition of the lung dust between the pathological groups. Lungs from men mining low rank coal, however, showed a striking increase in the proportion of ash over the pathological groups (M, F, and PMF). In men who had mined low rank coal the proportion of ash in the airborne dust to which they had been exposed and in the dust retained in their lungs was, as expected, greater than in men who had worked with higher rank coals. For the same men, and particularly associated with the presence of some dust related fibrosis, the proportion of ash in retained dust was higher than that in the dust to which the men were exposed suggesting the occurrence of selective deposition or retention of the mineral components of dust in this group.
\end{abstract}

Early work on miners from south Wales suggested that the pathological grade of pneumoconiosis was directly proportional to the mass of dust recovered from the lungs at necropsy ${ }^{1}$ and that the composition of the retained dust was little different from that encountered at the workplace. ${ }^{2}$ Progressive massive fibrosis (PMF) was considered to be either a complication resulting from a secondary factor, widely believed to be tuberculosis, or a form of silicosis.

Regional variations in the prevalence of pneumoconiosis, particularly PMF, prompted an interest in studies of miners from areas other than south Wales. The results showed that the amount of dust found in lungs from north west England was somewhat lower than in south Wales and that this dust had a significantly greater ash content. ${ }^{34}$ Subsequent work, covering most coalfields in Britain, indicated

Accepted 14 April 1986 that the composition of the lung dust was related to the rank of coal mined. ${ }^{5}$

At the same time the accumulation of dust in lungs was examined. Lungs from hauliers and other underground workers were shown to contain less dust and to accumulate less dust per year than those from colliers. ${ }^{1}$ Furthermore, the rate at which dust accumulated in the lungs of men without PMF was found to be related to coal rank, with men from collieries mining high rank coal accumulating dust faster than men mining low rank coal. ${ }^{5}$ This work also showed that men with PMF accumulated dust at a greater rate than men without. ${ }^{5}$

These studies made a major contribution to the understanding of the relation between occupational exposure to coalmine dust and the development of pneumoconiosis. They were, however, hampered by the lack of measurement of dust exposure other than "years underground." The purpose of the present 
study was to use more recently available estimates of life time exposures to respirable dust, based on between 10 and 20 years of measurements of respirable dust concentrations collected during the National Coal Board's Pneumoconiosis Field Research (PFR), ${ }^{6}$ to investigate the relation between calculated dust exposure and lung dust burden. A further aim was to determine whether this relation varied according to the pathological grade of pneumoconiosis and the type (rank) of coal mined.

\section{Materials and methods}

Between June 1972 and October 1977430 pairs of lungs were collected from coalminers who had been employed at the 24 PFR collieries representing the major British coalfields. Of these specimens, 414 were obtained from the pneumoconiosis medical panels who had examined them for evidence of pneumoconiosis for compensation purposes. Forty per cent of the men were not in receipt of compensation and a large proportion of them had not attended the panels. The remaining pairs of lungs were obtained from hospitals in the vicinity of coalmines by courtesy of the local pathologists.

The study group did not represent a random sample of the mining population nor of the PFR study population. It did, however, cover the broad range of lung disease associated with the mining industry and a wide range of dust exposure.

\section{PATHOLOGICAL EXAMINATION}

In most cases the lungs had been cut at necropsy or by the pneumoconiosis medical panel doctor before examination. This was normally in the sagittal plane and sectioning was completed where necessary. Each slice was examined for evidence of PMF and a respresentative slice from each lung was examined in more detail for numbers and sizes of dust lesions and extent of emphysema. The results of some analyses of these data have been described. ${ }^{78}$

Three pathological groups were defined according to the presence of particular dust lesions. Lungs assigned to group " $M$ " showed focal dust deposits with minimal evidence of fibrosis; those in group " $F$ " had, in addition, one or more fibrotic dusted lesions between $1 \mathrm{~mm}$ and $9 \mathrm{~mm}$ diameter; and those in the PMF group showed fibrotic dusted lesions $10 \mathrm{~mm}$ or more in diameter. Subjects in the $\mathbf{M}$ group, whose lungs showed only macules, rarely had radiographic evidence of pneumoconiosis. ${ }^{9}$

\section{LUNG DUST ANALYSIS}

After pathological examination one lung from each pair was used to determine the weight and composition of retained dust. Dust was extracted from representative samples of whole dried lung by hydro- $\overline{\bar{c}}$ lysis in $11.3 \mathrm{M}$ hydrochloric acid. ${ }^{10}$ After weighing, the dust was ashed in a muffle furnace and the coal $\frac{3}{\infty}$ content calculated from the weight loss. The quartz, ? kaolin, and mica content of the ash were determined using infrared spectrophotometry. ${ }^{11}$

The dust weight for both lungs was calculated by multiplying the measured dust weight by a factor to allow for the different ventilation of the left and right $\frac{\mathrm{N}}{\sigma}$ lungs. ${ }^{12}$ For this study the factors were 1.86 if the $\stackrel{\mathbb{D}}{\square}$ right lung had been used for dust analysis and 2.16 if the left lung had been used.

\section{DUST EXPOSURE}

Respirable dust concentrations were measured at 24 collieries for 12 years, starting in 1954, and measurements continued at 10 of these collieries into the 1970s. Two types of dust sampler were used. Until $\vec{\omega}$ 1968 airborne dust was sampled by the standard ther- $\vec{N}$ mal precipitator (STP) and its concentration and composition were determined by optical microscopy. $\mathcal{~} 0$ Latterly the MRE gravimetric dust sampler type $ᄋ$ $113 \mathrm{~A}$ was used, dust concentration being determined by mass and dust composition by infrared spectrophotometry. ${ }^{10}$ Factors for the conversion of the $\overbrace{}^{\mathbb{D}}$ earlier measurements to equivalent respirable gravi- $\stackrel{\mathbb{D}}{\exists}$ metric values were determined experimentally for $\underset{\mathbb{D}}{D}$ each of the 24 collieries. ${ }^{13}$ Additional compositional analyses of the samples collected using the STP wete $\bar{\emptyset}$ carried out by infrared spectrophotometry ${ }^{14}$ and the results obtained by optical microscopy were adjust accordingly.

Dust concentration and composition were measured for occupational groups which defined work type and location within a colliery. The cumulative $\stackrel{\varnothing}{\varnothing}$ dust exposure for each man was calculated from the recorded number of shifts worked in each occupational group and the corresponding dust concentration figures, and was expressed as gram hours per cubic metre of sampled air $\left(\mathrm{ghm}^{-3}\right)$.

For the period before PFR, cumulative dust exposures were estimated from the early PFR dust concentration measurements and data on working histories obtained by interview. The calculation of cumulative dust exposure is described elsewhere. ${ }^{15}$

Although there was considerable variation between miners in the proportions of the estimated component $\frac{9}{5}$ of the exposure, this has been found to have little effect on the various relations under investigation. ${ }^{16}$

COAL RANK classification the collieries were divided into four $\mathrm{\omega}$ groups according to the rank of coal mined. Rank of coal is a descriptive term for the position on the geo- $\stackrel{O}{\subset}$ logical "coalification" scale from lignite to anthracite. क 
Decreasing rank is associated with decreasing carbon and increasing "volatile" content. The groups were labelled A (94.0-91.4\% carbon), B (90.6-88.8\% carbon), C (87.0-85.2\% carbon), and D (85.5-81.1\% carbon) in order of decreasing coal rank.

Collieries included in the high rank groups A and B were in south Wales together with one from Kent and one from north east England. Those in the low rank groups C and D were in the Midlands and north of England, north Wales, and Scotland.

\section{ANALYSIS OF RESULTS}

The residual mean square values and associated degrees of freedom used in testing for differences in mean values between groups were derived using standard analysis of variance techniques.

\section{Results}

CUMULATIVE EXPOSURE TO RESPIRABLE DUST IN LIFE

For each coal rank group, subjects in the $M$ pathological group had been exposed to the least respirable dust in life and, in general, those in the PMF group to the most (table 1). There was a similar increase between the $\mathbf{M}$ and PMF groups in cumulative exposure to the non-coal mineral (ash) component of the dust (table 1).

When coal rank groups were compared within any pathological group it was noted that, for groups $F$ and PMF, men in the lowest rank group D had been exposed, on average, to less dust than men in other rank groups (table 1).

For all pathological groups, subjects from the highest rank collieries (rank group A) had been exposed to less ash (and its measured components quartz and kaolin plus mica) than those from lower rank collieries (table 1).

There were no obvious differences in the mean percentage composition of respirable dust between pathological groups from the same coal rank group but there was a significantly greater proportion of ash in respirable dust from low rank collieries when compared with the high rank groups (table 2).

An examination of the number of years of exposure showed that men with PMF from coal rank group A

Table 1 Mean cumulative exposure to respirable dust and its "non-coal mineral" portion for 430 men divided by pathological and coal rank groups. (Number of men for each group given in parentheses)

\begin{tabular}{|c|c|c|c|c|c|}
\hline \multirow[b]{2}{*}{ Component $\left(\mathrm{ghm}^{-3}\right)$} & \multirow[b]{2}{*}{ Pathological group } & \multicolumn{4}{|c|}{ Coal rank group } \\
\hline & & $A$ & $B$ & $C$ & $D$ \\
\hline $\begin{array}{l}\text { Respirable dust } \\
\text { Ash }^{*}\end{array}$ & $\mathbf{M}$ & $\begin{array}{l}136 \cdot 9 \\
36 \cdot 1(31)\end{array}$ & $\begin{array}{l}192.1 \\
61.9(26)\end{array}$ & $\begin{array}{l}238 \cdot 7 \\
92 \cdot 3(7)\end{array}$ & $\begin{array}{l}140 \cdot 6 \\
59 \cdot 6(26)\end{array}$ \\
\hline $\begin{array}{l}\text { Respirable dust } \\
\text { Ash }\end{array}$ & $\mathrm{F}$ & $\underset{59 \cdot 1 \dagger(61)}{228 \cdot 1 \dagger}$ & $\begin{array}{l}283 \cdot 5 \dagger \\
83 \cdot 9 \dagger(40)\end{array}$ & $\begin{array}{l}287 \cdot 8 \\
113 \cdot 0(30)\end{array}$ & $\begin{array}{l}194 \cdot 6 \\
90 \cdot 6+(43)\end{array}$ \\
\hline $\begin{array}{l}\text { Repirable dust } \\
\text { Ash }\end{array}$ & PMF & $\begin{array}{l}273 \cdot 8 \dagger \\
67 \cdot 5 \dagger(49)\end{array}$ & $\begin{array}{l}283.6 \dagger \\
82.0(39)\end{array}$ & $\begin{array}{l}303.1 \\
120.8(37)\end{array}$ & $\begin{array}{l}184 \cdot 8 \\
84 \cdot 7 \dagger(41)\end{array}$ \\
\hline $\begin{array}{l}\text { Residual } \\
\text { mean sqs }\end{array}$ & $\begin{array}{l}\text { Respirable dust }=15018 \\
\text { Ash }=1697\end{array}$ & \multicolumn{4}{|c|}{ (418 degrees of freedom) } \\
\hline
\end{tabular}

*Ash is the non-coal mineral portion of the respirable dust.

†Difference from $M$ group $\mathrm{p}<0.05$.

Table 2 Mean percentages of ash and of quartz in dust exposure for 430 men divided by pathological and coal rank groups

\begin{tabular}{|c|c|c|c|c|c|}
\hline \multirow[b]{2}{*}{ Component } & \multirow[b]{2}{*}{ Pathological group } & \multicolumn{4}{|c|}{ Coal rank group } \\
\hline & & $A$ & $\boldsymbol{B}$ & $C$ & $D$ \\
\hline $\begin{array}{l}\text { Ash* } \\
\text { Quartz }\end{array}$ & $\mathbf{M}$ & $\begin{array}{r}27 \cdot 6 \\
3.5\end{array}$ & $\underset{32.8}{32.4 t t}$ & $\underset{3 \cdot 4}{44 \cdot 3+t}$ & $\underset{4 \cdot 3}{41 \cdot 6 \ddagger}$ \\
\hline $\begin{array}{l}\text { Ash } \\
\text { Quartz }\end{array}$ & F & $\begin{array}{r}27 \cdot 1 \\
2 \cdot 8\end{array}$ & $\begin{array}{r}31 \cdot 0+\ddagger \\
4 \cdot 0+\ddagger\end{array}$ & $\begin{array}{r}41 \cdot 0 \dagger \ddagger \\
4 \cdot 8+\ddagger\end{array}$ & $\begin{array}{c}45 \cdot 3 \dagger \ddagger \\
5 \cdot 4 \ddagger\end{array}$ \\
\hline $\begin{array}{l}\text { Ash } \\
\text { Quartz }\end{array}$ & PMF & $\begin{array}{r}25.8 \\
2.9\end{array}$ & $\begin{array}{r}30 \cdot 4+\ddagger \\
4 \cdot 3+\ddagger\end{array}$ & $\underset{41 \cdot 4 \ddagger \ddagger}{4 \cdot 4 \ddagger}$ & $\begin{array}{r}44 \cdot 7 \dagger t \\
5 \cdot 1+t\end{array}$ \\
\hline $\begin{array}{l}\text { Residual } \\
\text { mean sqs }\end{array}$ & $\begin{array}{l}\text { Ash }=50.9 \\
\text { Quartz }=1.9\end{array}$ & \multicolumn{4}{|c|}{ (418 degrees of freedom) } \\
\hline
\end{tabular}

*Ash is the non-coal mineral portion of the dust exposure of which quartz is a component.

†Difference from next highest rank group $\mathrm{p}<0.05$.

$\ddagger$ Difference from rank group A p $<0.05$. 
had been exposed for a shorter time (mean 34 years) than men with PMF from the other rank groups (mean 41-44 years). In coal rank groups $B$ and $C$ men with PMF had significantly longer mean periods of exposure (41 years) than men in the $M$ pathological group (27-35 years). Differences in periods of exposure to respirable dust between groups were otherwise relatively small.

\section{DUST RETAINED IN THE LUNG}

Within each coal rank group there was an increase in the mass of retained dust and its measured components over the pathological range $M \rightarrow F \rightarrow P M F$. Table 3 shows the mean values for total retained dust and ash.

For each pathological group the mean mass of retained dust did not differ between coal ranks with the exception that men with PMF who had mined high rank coal had a significantly greater mass of dust in their lungs (table 3). The mean weights of ash and its measured components, quartz and kaolin plus mica, however, were greater in the lower coal rank groups, being highest for rank group $\mathrm{C}$ (table 3 ). Thus a greater proportion of ash and its components was present in the retained dust from men in lower rank groups (table 4).

Although the mean weights of ash and its measured components increased over the pathological range for all coal rank groups (table 3), a significant increase in the proportion of ash between pathological groups was seen only in men from rank groups $C$ and $D$ (table 4).

\section{RELATION BETWEEN DUST EXPOSURE AND RETAINED DUST}

For all coal rank groups it was found that subjects with PMF had retained more dust (and each of its measured components) per unit of dust exposure than those in pathological groups $M$ and $F$ (table 5).

The retention of dust components was further examined using the following ratio:

$\frac{\text { percentage of component in retained dust }}{\text { percentage of component in respirable dust exposure }}$

Table 3 Mean weights of dust and of ash retained in the lungs of subjects divided by pathological and coal rank groups

\begin{tabular}{|c|c|c|c|c|c|}
\hline \multirow[b]{2}{*}{ Component $(\mathrm{g})$} & \multirow[b]{2}{*}{ Pathological group } & \multicolumn{4}{|c|}{ Coal rank group } \\
\hline & & $A$ & $B$ & $C$ & $D$ \\
\hline $\begin{array}{l}\text { Whole dust } \\
\text { Ash* }\end{array}$ & $\mathbf{M}$ & $\begin{array}{l}5 \cdot 4 \\
1 \cdot 2\end{array}$ & $\begin{array}{l}5 \cdot 8 \\
1.6\end{array}$ & $\begin{array}{r}15 \cdot 2 \\
4 \cdot 8\end{array}$ & $\begin{array}{l}7.0 \\
2 \cdot 8\end{array}$ \\
\hline $\begin{array}{l}\text { Whole dust } \\
\text { Ash }\end{array}$ & $\mathbf{F}$ & $\underset{2 \cdot 3}{13 \cdot 0 \dagger}$ & $\begin{array}{c}14 \cdot 2 \dagger \\
4 \cdot 2\end{array}$ & $\begin{array}{r}12 \cdot 0 \\
6 \cdot 2\end{array}$ & $\begin{array}{l}11 \cdot 3 \\
5 \cdot 7 \dagger\end{array}$ \\
\hline $\begin{array}{l}\text { Whole dust } \\
\text { Ash }\end{array}$ & PMF & $\begin{array}{r}26 \cdot 4+\ddagger \\
5 \cdot 1+\ddagger\end{array}$ & $\begin{array}{r}18 \cdot 2 \dagger \\
5 \cdot 4 \dagger\end{array}$ & $\begin{array}{c}20 \cdot 5 \ddagger \\
9 \cdot 7 \ddagger \ddagger\end{array}$ & $\begin{array}{c}15 \cdot 0 \dagger \\
8 \cdot 7 \dagger \ddagger\end{array}$ \\
\hline $\begin{array}{l}\text { Residual } \\
\text { mean sqs }\end{array}$ & $\begin{array}{l}\text { Whole dust }=101.4 \\
\text { Ash }=12.9\end{array}$ & \multicolumn{4}{|c|}{ (418 degrees of freedom) } \\
\hline
\end{tabular}

*Ash is the non-coal mineral portion of the dust.

+ Difference from $M$ group $p<0.05$.

$\ddagger$ Difference from $F$ group $\mathrm{p}<0.05$.

Table 4 Mean percentage ash and percentage quartz in retained dust for subjects divided by pathological and coal rank groups

\begin{tabular}{|c|c|c|c|c|c|}
\hline \multirow[b]{2}{*}{ Component } & \multirow[b]{2}{*}{ Pathological group } & \multicolumn{4}{|c|}{ Coal rank group } \\
\hline & & $A$ & $B$ & $C$ & $D$ \\
\hline $\begin{array}{l}\text { Ash* } \\
\text { Quartz }\end{array}$ & $\mathbf{M}$ & $\begin{array}{r}21 \cdot 3 \\
3 \cdot 0\end{array}$ & $\underset{4 \cdot 3}{29 \cdot 4 \dagger \ddagger}$ & $\underset{5 \cdot 1}{35 \cdot 7 \ddagger}$ & $\begin{array}{r}39 \cdot 1 \ddagger \\
6 \cdot 1 \ddagger\end{array}$ \\
\hline $\begin{array}{l}\text { Ash } \\
\text { Quartz }\end{array}$ & $\mathbf{F}$ & $\begin{array}{r}21 \cdot 6 \\
3 \cdot 2\end{array}$ & $\begin{aligned} 32 \cdot 7+\ddagger \\
5 \cdot 4+\ddagger\end{aligned}$ & $\begin{array}{r}49 \cdot 4 t \ddagger \\
9 \cdot 6+\ddagger\end{array}$ & $\begin{array}{r}49 \cdot 1 \ddagger \\
8 \cdot 5 \ddagger\end{array}$ \\
\hline $\begin{array}{l}\text { Ash } \\
\text { Quartz }\end{array}$ & PMF & $\begin{array}{r}22.5 \\
3.6\end{array}$ & $\begin{array}{r}32 \cdot 9+\ddagger \\
5 \cdot 9+\ddagger\end{array}$ & $\begin{array}{r}50 \cdot 5+\ddagger \\
9 \cdot 1+\ddagger\end{array}$ & $\begin{array}{l}58 \cdot 7+\ddagger \\
11 \cdot 2+\ddagger\end{array}$ \\
\hline $\begin{array}{l}\text { Residual } \\
\text { mean sqs }\end{array}$ & $\begin{array}{l}\text { Ash }=186.7 \\
\text { Quartz }=9.6\end{array}$ & \multicolumn{4}{|c|}{ (418 degrees of freedom) } \\
\hline
\end{tabular}

${ }^{*}$ Ash is the non-coal mineral portion of the dust of which quartz is a component.

$\dagger$ Difference from next highest rank group $p<0.05$.

$\ddagger$ Difference from rank group A p $<0.05$. 
Table 5 Estimated slopes (and standard errors) for comparisons of retained lung dust with respirable dust exposure for 430 men divided by pathological and coal rank groups. (Standard errors given in parentheses)

\begin{tabular}{|c|c|c|c|c|c|c|c|c|}
\hline \multirow[b]{3}{*}{ Pathological group } & \multicolumn{8}{|c|}{ Retained lung dust $=$ coefficient $\times$ respirable exposure $\times 10^{-2}$ (or component $)$} \\
\hline & \multicolumn{4}{|c|}{ For total dust coal rank group } & \multicolumn{4}{|c|}{ For Ash* coal rank group } \\
\hline & $A$ & $B$ & $C$ & $D$ & $A$ & $B$ & $C$ & $D$ \\
\hline $\begin{array}{l}\mathbf{M} \\
\mathbf{F} \\
\text { PMF }\end{array}$ & $\begin{array}{l}3 \cdot 2(1 \cdot 1) \\
5 \cdot 2(0 \cdot 5) \\
7 \cdot 2(0 \cdot 5)\end{array}$ & $\begin{array}{l}2.6(1.0) \\
4.9(0 \cdot 6) \\
6.0(0 \cdot 6)\end{array}$ & $\begin{array}{l}6.0(1.4) \\
3.7(0.7) \\
6.2(0.6)\end{array}$ & $\begin{array}{l}4.9(1.3) \\
4.3(0.7) \\
6.8(0.8)\end{array}$ & $\begin{array}{l}2.9(1.5) \\
3.6(0.7) \\
6.0(0.7)\end{array}$ & $\begin{array}{l}2.2(1.0) \\
5.0(0.7) \\
6.1(0.7)\end{array}$ & $\begin{array}{l}4 \cdot 5(1 \cdot 3) \\
5 \cdot 3(0 \cdot 6) \\
7 \cdot 0(0 \cdot 5)\end{array}$ & $\begin{array}{l}5 \cdot 1(1.0) \\
5.0(0.5) \\
8.7(0.6)\end{array}$ \\
\hline
\end{tabular}

*Ash is the non-coal mineral portion of dust.

Table 6 Mean values for the ratio of percentage lung dust component to the percentage of the same component in respirable coalmine dust divided by pathological and coal rank groups

\begin{tabular}{|c|c|c|c|c|c|}
\hline \multirow[b]{2}{*}{ Component } & \multirow[b]{2}{*}{ Pathological group } & \multicolumn{4}{|c|}{ Coal rank group } \\
\hline & & $A$ & $B$ & $C$ & $D$ \\
\hline $\begin{array}{l}\text { Ash* } \\
\text { Quartz }\end{array}$ & $\mathbf{M}$ & $\begin{array}{l}0.80 \\
0.99\end{array}$ & $\begin{array}{l}0.92 \\
1.23\end{array}$ & $\begin{array}{l}0.79 \\
1.44\end{array}$ & $\begin{array}{l}0.93 \\
1.45\end{array}$ \\
\hline $\begin{array}{l}\text { Ash } \\
\text { Quartz }\end{array}$ & $\mathbf{F}$ & $\begin{array}{l}0.82 \\
1 \cdot 16\end{array}$ & $\begin{array}{l}1.06 \\
1.46\end{array}$ & $\begin{array}{l}1.24 \dagger \\
2 \cdot 16 \dagger\end{array}$ & $\begin{array}{l}1 \cdot 10 \\
1 \cdot 66\end{array}$ \\
\hline $\begin{array}{l}\text { Ash } \\
\text { Quartz }\end{array}$ & PMF & $\begin{array}{l}0.87 \\
1.27\end{array}$ & $\begin{array}{l}1.09 \\
1.47\end{array}$ & $\begin{array}{l}1.21 \dagger \\
2.08 \dagger\end{array}$ & $\begin{array}{l}1 \cdot 33+t \\
2 \cdot 35+t\end{array}$ \\
\hline $\begin{array}{l}\text { Residual } \\
\text { mean sqs }\end{array}$ & $\begin{array}{l}\text { Ash }=0.14 \\
\text { Quartz }=0.59\end{array}$ & \multicolumn{4}{|c|}{ (418 degrees of freedom) } \\
\hline
\end{tabular}

*Ash is the non-coal mineral portion of the exposure dust of which quartz is a component.

+ Difference from next $\mathbf{M}$ group $\mathbf{p}<0.05$.

tDifference from $F$ group $p<0.05$.

Table 6 presents mean values of this ratio calculated for ash and quartz for subjects arranged by pathological and coal rank groups. The pattern of results for kaolin plus mica was similar to that for quartz. For subjects with some lung fibrosis $(F$ and PMF pathological groups) in the lower coal rank groups, $C$ and $\mathrm{D}$, the proportion of ash in the retained lung dust is greater than in the dust to which the men were exposed. This difference is most striking for the measured ash components, quartz and kaolin plus mica; for men with fibrotic nodules from coal rank $\mathrm{C}$ and men with PMF from ranks $C$ and $D$ the proportion of quartz in the lung dust was, on average, more than twice that measured in the respirable coalmine dust.

\section{Discussion}

Interest in the relation between the dust retained in the lungs of coalworkers and that to which they were exposed centres on two particular issues. The first concerns how far the amount of dust retained reflects the lifetime exposure of an individual; the second considers the effect of dust composition on this relation.

Previous studies have used broad indices of exposure such as years spent underground or an overall figure for exposure to dust. For this series of men the availability of measured exposure to respirable dust from Pneumoconiosis Field Research has provided a unique opportunity to investigate the relation more closely.

In addition to finding that the lungs from men with PMF contained on average more dust than the lungs from men who do not have PMF we have been able to demonstrate that men with PMF accumulated more dust per unit exposure than men without. This suggests that lung dust burdens are not simply a reflection of dust exposure but that patterns of deposition or clearance, or both, may differ between men who develop PMF and those who do not. Such differences are unlikely to be due to a single factor. It may be that clearance of dust is impaired by the splinting effect of fibrosis on the lung; further examination of available data showed that, in men working high rank coal, the accumulation per unit of exposure did increase with increasing size of the PMF lesions. It is equally possible that differences in accumulation of dust, for whatever reason (breathing rates physical characteristics, for example) are a factor in the development of PMF. The present data are not suitable for the examination of such a hypothesis.

The dust exposure data used in this study are based on measurements of respirable dust concentrations. While it is recognised that there are well defined differences in the sampling efficiencies between the 
alveoli and respirable dust samplers it has generally been believed that these are not important in epidemiological studies. Recent work in Germany, however, has suggested that these differences are relevant. ${ }^{17}$ In particular the relation between respirable dust concentrations and "alveolar disposition" dust concentrations was found to be dependent on ash content. It was concluded that the use of respirable dust concentrations would result in a serious overestimate of dust exposure where the dust contained a high proportion of ash. If this was the case then we might expect that men who had been exposed to low rank (high ash) coal would have retained less dust per unit exposure than men who had mined high rank coal. That such differences were not observed suggests that there were no systematic variations in the measurements of respirable dust concentrations with coal rank.

The second point of interest in the relation between retained dust and dust exposure relates to differences in dust composition. We have shown that dust from the lungs of men with fibrotic nodules or PMF who had mined low rank coals contained a higher proportion of ash than was recorded in the mine dust. Further, the proportion of quartz in the lung dust was up to twice that in the respirable dust to which the men were exposed. This has been observed in other studies of coalworkers ${ }^{18}$ and of hard rock workers. ${ }^{19}$ There are no simple explanations for this observation but, in tracing the sequence from exposure to alveolar deposition, several factors may be examined.

Given that maximum alveolar deposition is afforded to particles between 2 and $4 \mu \mathrm{m}$, if the ash components of respirable dust contribute more of the smaller particles than the coal ${ }^{20}$ then proportionately more ash may be deposited. While the mean volume median diameters of respirable mine dusts collected by MRE type 113A gravimetric samplers range from $2 \cdot 5$ to $6 \cdot 5 \mu \mathrm{m}$ equivalent spherical diameter (esd) ${ }^{21}$ those measured for lung dust in the present study lay between 1.6 and $3.5 \mu \mathrm{m}$ esd. There is, therefore, some evidence that proportionately more ash may reach the alveoli than would be predicted from the composition of mine dust collected by the sampler but this alone cannot explain the differences between pathological groups. A further possibility that could influence the relative retention of mineral components is that a figure for cumulative exposure may conceal short periods of exposure to exceptionally high concentrations of dust with a composition considerably different from that regularly encountered. It is known that short periods of exposure to high quartz levels may be associated with an increase in the radiological progression of pneumoconiosis ${ }^{22}$ but the effects of such short periods on lung dust burden and composition have not been ascertained.
The apparent concentration of quartz in the lung dust from men in the F and PMF groups from low rank collieries is of particular interest in the light of our recent finding that dust composition is associated with distinctive histological patterns of pneumoconiotic lesion, a more fibrogenic response being related to dust containing a high proportion of ash. ${ }^{23}$ The more fibrogenic response to the ash component of dusts may lead to its sequestration in the lung whereas coal is removed by way of the mucociliary escalator or by macrophage activity. It has been suggested that the presence of other minerals, particularly mica, may reduce the fibrogenicity of quartz present in coal mine dusts. ${ }^{24}$ This protective effect has not so far been explored in our current studies.

We consider that further investigations into the relation between dust exposure, lung dust burden, and the ensuing pathological response is required. In the present work, for example, the men have been divided into three broad groups according to the presence of absence or fibrotic lesions of different sizes; further work should include examination of the relation taking account of more detailed pathological information and some of the more complex interactions between dust components, periods of exposure, and time out of the industry. Such research is fundamental to an understanding of how much dust encountered at the workplace will causes significant disease.

We are grateful to many colleagues in Pneumos coniosis Field Research who collected exposure data, to the pneumoconiosis medical panels who supplied necropsy material, and to the Institute staff for their technical expertise. In particular we thank Dr JM Fernie for her constructive comments on the text. The study was jointly funded by the National Coal Board and the Commission of European Communities. (Contract 7246-15/8/001.)

\section{References}

1 King EJ, Maguire BA, Nagelschmidt G. Further studies in the dust in lungs of coalminers. Br $J$ Ind Med 1956;13:9-23.

2 King EJ, Nagelschmidt G. The mineral content of the lungs of workers from the south Wales coalfield. In: Medical Research Council. Chronic pulmonary disease in south Wales colaminers. III. Experimental studies. London: HMSO, 1945. (MRC special report series No 250.)

3 Faulds JS, King EJ, Nagelschmidt G. The dust content of the lungs of coalworkers from Cumberland. $\mathrm{Br} J$ Ind Med 1959;16:433-50.

4 Spink R, Nagelschmidt G. Dust and fibrosis in the lungs of coalworkers from the Wigan area of Lancashire. $\mathrm{Br} J$ Ind Med 1963;20:118-23.

5 Bergman I, Casswell C. Lung dust and lung iron in different coalfields in Britain. Br J Ind Med 1972;29:160-8.

6 Fay JWJ, Rae S. The pneumoconiosis field research of the National Coal Board. Ann Occup Hyg 1959;1:149-61.

7 Ruckley VA, Gauld SJ, Chapman JS, et al. Emphysema and dust 
exposure in a group of coalworkers. Am Rev Respir Dis 1984;129:528-32.

8 Ruckley VA, Fernie JM, Chapman JS, et al. Comparison of radiographic appearances with associated pathology and lung dust content in a group of coalworkers. $\mathrm{Br} \mathrm{J}$ Ind $\mathrm{Med}$ 1984;41:459-67.

9 Davis JMG, Chapman J, Collings P, et al. Autopsy study of coalminers lungs. (Final report on CEC contract No 6244-00/8/103.) Edinburgh: Institute of Occupational Medicine, 1979. (IOM report No TM/79/9.)

10 Guest $\mathrm{L}$. The recovery of dust from formalin fixed pneumoconiotic lungs: a comparison of methods used at SMRE. Ann Occup Hyg 1976;19:37-47.

11 Dodgson $\mathrm{J}$, Whittaker $\mathrm{W}$. The determination of quartz in respirable dust samples by infrared spectrophotometry. I. The potassium bromide disc method. Ann Occup Hyg 1973;16:373-87.

12 Svanberg $L$. Influence of posture on the lung volume, ventilation and circulation in normals. A spirometric-broncho-spirometric investigation. Scand J Clin Lab Med 1957;9:suppl 25.

13 Dodgson J, Hadden GG, Jones CO, Walton WH. Characteristics of the airborne dust in British coal mines. In: Walton WH, ed. Inhaled particles III. Old Woking, Surrey: Unwin Bros, 1977:757-82.

14 Dodgson J, Cowie AJ, Paris I, Whittaker W. A study of the importance of dust composition in relation to pneumoconiosis in coalminers. (Final report of CEC contract No 625-32/8/018.) Edinburgh: Institute of Occupational Medicine, 1977. (IOM report No TM/77/8.)

15 Hurley JF, Burns J, Copland E, Dodgson J, Jacobsen M. Coalworkers simple pneumoconiosis and exposure to dust at 10 British coalmines. Br J Ind Med 1982;39:120-7.

16 Ruckley VA, Chapman JS, Collins P, et al. Autopsy studies of coalminers' lungs - phase II. (Final report on CEC contract 7246-15/8/001.) Edinburgh: Institute of Occupational Medicine, 1981. (IOM report No TM/81/18.)

17 Reinhardt M, Reisner MTR. Vergleichsmessungen mit dem gravimetrischen Staubprobennahmegeraten MPGII und TBF50. Ergebnisse von Untersuchungen auf dem Gebeit der Staub-und Silikosebekampfung in Steinkohlenbergbau. Essen: Verlag Gluckauf, Band 13; 1981:121-31.

18 Leiteritz H, Einbrodt H, Klosterkotter W. Grain size and mineral content of lung dust of coalminers compared with mine dust. In: Davies CN, ed. Inhaled particles II. Oxford: Pergamon Press, 1967:381-90.

19 Verma DK, Muir DCF, Stewart ML, Julian JA, Ritchie AC. The dust content of the lungs of hard-rock miners and its relationship to occupational exposure, pathological and radiological findings. Ann Occup Hyg 1982;26:401-9.

20 Breuer $\mathrm{H}$. Size distributions of dust from coal mines and its influence on the results of gravimetric measuring processes with and without size selection. In: Davies $\mathrm{CN}$, ed. Inhaled particles II. Oxford: Pergamon Press, 1967:549-60.

21 Ogden TL, Rickman AR. Characterisation of the volume size distribution of respirable coal-mine dust samples by Coulter counter. Ann Occup Hyg 1977;20:257-70.

22 Seaton A, Dick J, Dodgson J, Jacobsen M. Quartz and pneumoconiosis in coalminers. Lancet 1983;ii:1272-5.

23 Davis JMG, Chapman J, Collings $P$, et al. Variations in the histological patterns of the lesions of coalworkers' pneumoconiosis in Britain and their relationship to lung dust content. Am Rev Respir Dis 1983;128:118-24.

24 Le Bouffant L, Daniel H, Martin JC, Bruyere S. Effect of impurities and associated minerals on quartz toxicity. Ann Occup Hyg 1982;26:625-34.

\section{Correspondence and editorials}

The British Journal of Industrial Medicine welcomes correspondence relating to any of the material appearing in the journal. Results from preliminary or small scale studies may also be published in the correspondence column if this seems appropriate. Letters should be not more than 500 words in length and contain a minimum of references. Tables and figures should be kept to an absolute minimum. Letters are accepted on the understanding that they may be subject to editorial revision and shortening.

The journal now also publishes editorials which are normally specially commissioned. The Editor welcomes suggestions regarding suitable topics; those wishing to submit an editorial, however, should do so only after discussion with the Editor. 